\title{
Key Ideas on Mobility and Social Security after Brexit
}

\section{Dolores Carrascosa Bermejo ${ }^{1,2}$}

Accepted: 9 August 2021 / Published online: 30 August 2021

(c) The Author(s) 2021

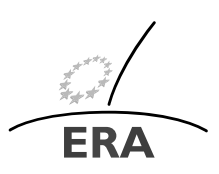

EUROPÄISCHE RECHTSAKADEMIE ACADEMY OF EUROPEAN LAW ACADEMIE DE DROIT EUROPEEN ACCADEMIA DI DIRITTO EUROPEO TRIER - TREVES - TREVIRI

\begin{abstract}
This article provides a general understanding of the main aspects of mobility (no longer referred to as free movement) and social security coordination, in the Brexit international agreements that govern the relationship of the EU with the United Kingdom: the Withdrawal Agreement (WA) and the Trade and Cooperation Agreement (TCA). The article shows that both topics, mobility (or migration) and social security coordination, were relevant to the origins of Brexit. Before analysing both Brexit Agreements, the article gives a comparative overview of them, considering their principal features and their relationship. The article then analyses the mobility and coordination of social security in each agreement from a practical perspective, giving examples and highlighting the significant differences in coverage that they generate for the different citizens included in their personal scope.
\end{abstract}

Keywords Brexit - Withdrawal Agreement - Trade and Cooperation Agreement . Mobility · Social security coordination - Social security protocol · Gibraltar . Posting of workers · Free movement · EUSS · Transition period · Pre-Brexit citizens $\cdot$ EU coordination Regulations

\section{Introduction}

This article aims to provide a general understanding of the main aspects of mobility and social security coordination in the Brexit international agreements that now govern the relationship of the European Union with the United Kingdom: the Withdrawal

The author is Prof. PhD. at Universidad Complutense de Madrid and Universidad Pontificia Comillas. MoveS national and analytical expert. Editor at Lefebvre.

D. Carrascosa Bermejo

marcar15@ucm.es

1 Universidad Complutense de Madrid, Madrid, Spain

2 Universidad Pontificia Comillas, Madrid, Spain 
Agreement (WA Withdrawal Agreement) ${ }^{1}$ and the Trade and Cooperation Agreement (TCA). ${ }^{2}$

Before analysing mobility (not free movement, as there is no free movement with the United Kingdom any more) and the coordination of social security in the international agreements, I will briefly explain the importance of both issues in the origins of Brexit itself.

\section{Free movement of workers and social security coordination at Brexit's origins}

This article is not going to digress into the "social" origins of Brexit $[9,10,18,20] .{ }^{3}$ However, it seems necessary to underline very briefly the relevance of these two issues (mobility and social security coordination) to Brexit itself, which are the main subject of this article. In this regard, it appears relevant to highlight the following milestones which could arguably show such an impact:

In 2004, the UK promoted that year's major enlargement of the European Union, resulting in eight new Member States joining the European Union. The UK (like Ireland and Sweden) did not exercise its right to impose transitional measures on the free movement for citizens of these new Member States, as many other states did for as long as seven years. ${ }^{4}$ The UK decided to have free movement from the first moment, instead of limiting migration temporarily, and in the first year, more than 100,000 migrants from the new Member States arrived at the UK. In 2008, with an economic crisis and more than a million "unexpected" European Union migrants, public concern in the UK started to grow, as they felt they were victims of social tourism even if the evidence did not confirm this sentiment. ${ }^{5}$ Apparently, there was pressure on public services, schools, and the national healthcare system (with its many doctors and nurses from other Member States) and on housing. Migrants were also blamed for the downward pressure on the lowest salaries. ${ }^{6}$

In 2013, the crisis turned free movement into a risk for some Member States. The Home affairs ministers of four Member States (Austria, Germany, Netherlands, and UK) sent an unusual letter to the Irish justice minister, as Ireland then held the

\footnotetext{
${ }^{1}$ Agreement on the withdrawal of the United Kingdom of Great Britain and Northern Ireland from the European Union and the European Atomic Energy Community2019/C 384 I/01. https://eur-lex.europa.eu/ legal-content/EN/TXT/?qid=1580206007232\&uri=CELEX\%3A12019W/TXT\%2802\%29.

${ }^{2}$ Trade and Cooperation Agreement between the European Union and the European Atomic Energy Community, of the one part, and the United Kingdom of Great Britain and Northern Ireland, of the other part. ST/5198/2021/INIT. https://eur-lex.europa.eu/legal-content/EN/TXT/?uri=uriserv\%3AOJ.L_. 2021.149.01.0010.01.ENG\&toc=OJ\%3AL\%3A2021\%3A149\%3ATOC.

${ }^{3}$ See on this topic: Strban [20], p. 167. García de Cortázar y Nebreda [10], p. 1-5. and [9], p. 35-58, and Ribes Moreno [18].

${ }^{4}$ Underlying the non-existence of transitional measures to the free movement of persons in UK, see, among others, Pérez Flores [17], p. 17-36. See also Catherine Barnard's video "Can free movement of workers be stopped?"(2014). https://www.youtube.com/watch?v=_WQXb590Eq8.

${ }^{5}$ See Roberts [19], p. 535 et seq., considering the data exposed in Dustmann and Frattini [5]. See also ICF GHK Milieu [13] and Espín Sáez [8], p. 56-70.
}

${ }^{6}$ See Strban [20], p. 167. 
rotating presidency of the European Council, asking for a "correction" in rights linked with the free movement of European Union citizens. ${ }^{7}$ The Commission tried from the very beginning to prove them wrong with figures and reports and issued a firm Communication ${ }^{8}$ defending free movement.

The British answer to this situation was trying to control immigration, something which seemed impossible under European Union free movement rights. ${ }^{9}$ In that situation, Prime Minister Cameron promised a Brexit referendum and won the general election again, this time with unexpected majority. One year later, in 2016, the year of the Brexit referendum, there was such pressure that the European Council on 18 and 19 February established a special status for the UK, through a legally binding Decision that was conditional on the outcome of the vote. ${ }^{10}$ The European Council, in an effort to please the UK, made offers that, in this writer's opinion, undermined basic principles of European Union social law. As the British voted for Brexit, fortunately, the EU Decision in question never came into force, but among its other advantages were that it enabled the UK to limit access to work-related social benefits during the first four years and it envisaged the indexation of family benefits for those migrants' children who remained in the State of origin, without indexing the attached contributions.

At the same time, there was a highly controversial judgment of the European Court of Justice, which also seemed to involve an effort to try to calm the mood in the UK. In a nutshell, the judgment in case C-308/14 Commission v United Kingdom stated that checking administrative or legal residence as a condition for access to family benefits was not indirect discrimination on grounds of nationality, because the refusal was justified by the need to safeguard UK finances from inactive nationals of other Member States. ${ }^{11}$ A week after this judgment, on 23 June 2016, the UK voted in favour of Brexit and ended up being the first Member State to leave the European Union.

Now, nearly five years later, we are here dealing with these two international agreements, born in a difficult and strange negotiation. ${ }^{12}$ As Pascal Lamy, the former head of the World Trade Organisation, stated, "this will be the first negotiation in history where both parties started off with free trade and discussed what barriers to erect."13

\footnotetext{
${ }^{7}$ See http://docs.dpaq.de/3604-130415_letter_to_presidency_final_1_2.pdf.

${ }^{8}$ Communication from the Commission to the European Parliament, the Council, the European Economic and Social Committee and the Committee of the Regions. Free movement of EU citizens and their families: Five actions to make a difference Brussels, 25.11.2013. COM(2013) 837 final. https://eur-lex.europa.eu/ legal-content/EN/TXT/PDF/?uri=CELEX:52013DC0837\&from=HR.

${ }^{9}$ In 2014, the restrictions on the free movement of Romanian and Bulgarian citizens, who joined the EU in 2007 , ended.

${ }^{10}$ https://eur-lex.europa.eu/legal-content/EN/TXT/PDF/?uri=CELEX:52016XG0223(01)\&from=ES.

${ }^{11}$ According to the judgment, the Commission "has not provided evidence or arguments showing that such checking does not satisfy the conditions of proportionality, that it is not appropriate for securing the attainment of the objective of protecting public finances or that it goes beyond what is necessary to attain that objective". See criticisms of this ruling (ECLI:EU:C:2016:436), which changed the perspective on European citizenship: among others; O'Brien [16] and [15], p. 209-243, and Carrascosa Bermejo [2], p. 195 et seq.

${ }^{12}$ Regarding the "social security" negotiation see Roberts [19], p. 535 et seq. and Verschueren [23].

${ }^{13}$ https://www.ft.com/content/cc6b0d9a-d8cc-4ddb-8c57-726df018c10e.
} 


\section{The Brexit Agreements comparative overview}

Since January 2021, we have two parallel international agreements between the European Union and the UK, both in force and fully applicable. The Withdrawal Agreement (WA), signed at the end of 2019, and the Trade and Cooperation Agreement (TCA), signed at the end of 2020. They were agreed at the last minute, so all parties involved, the European Union and the States also adopted no deal contingency rules just in case. ${ }^{14}$

As a first key point, it is worth underlining that the TCA does not replace nor supersede any part of the WA. ${ }^{15}$ Both are simultaneously applicable but not to the same people at the same time. In fact, where the WA applies the TCA must be ruled out. This is the case as regards mobility, and in a certain way, social security coordination for the privileged citizens under the WA. For them, the TCA would not be applicable.

As can be seen in the comparative chart included at the end of this section, the agreements are very different.

Firstly, the WA is a shorter text that was carefully negotiated for two and a half years, was approved by the end of 2019 and entered into force in February 2020, when the UK became a third country to the European Union, but a transition period operated until the end of 2020. During this period, the United Kingdom did not participate in the European Union institutions (i.e., the EU Parliament, Commission, Council, the Court of Justice of the European Union etc.), but EU Law was completely applicable in the UK, all the while the second agreement was negotiated. ${ }^{16}$ For citizens nothing changed, and the Single Market continued functioning. In practice, the WA was not applied until January 2021.

The TCA, in turn, is a gigantic text of over 2,500 pages that was drafted in less than a year, ${ }^{17}$ during the pandemic, and that had to be provisionally applied before the definite version was approved. The provisional version was approved at the end of 2020 and entered into force on the first day of January 2021, also provisionally, the definitive version not being published in the EU official journal until 30 April 2021 and entered into force the first of May 2021.

The objectives of each agreement also clearly differed. The WA aims at "protecting citizens who have built their lives on the basis of rights flowing from UK membership of the EU". ${ }^{18}$ In other words, it preserves the rights of around 5 mil-

\footnotetext{
${ }^{14}$ Before the WA, see, for instance, the Regulation (EU) 2019/500 and in Spain, Royal Decree-law 5/2019 based on the reciprocity principle. https://www.boe.es/eli/es/rdl/2019/03/01/5. EU and National transitional rules that were not implemented because the WA was finally signed and entered into force. See Martín-Pozuelo López [14], p. 163-164. Before the TCA, Spain approved the Royal Decree-law 38/2020. https://www.boe.es/eli/es/rdl/2020/12/29/38.

${ }^{15}$ See Commission's answer to the question: "How does this Agreement relate to the Withdrawal Agreement concluded in January 2020?" Questions \& Answers: EU-UK Trade and Cooperation Agreement https://ec.europa.eu/commission/presscorner/detail/en/qanda_20_2532.

${ }^{16}$ This is not such a strange situation for the EU, as there are third countries applying free movement rules and coordination regulations, because it is envisaged under an international agreement. This is the case as regards Switzerland and the EFTA countries (Norway, Iceland, and Liechtenstein) because of the European Economic Area Agreement.

${ }^{17}$ The negotiation formally started the 2 of March 2020.

18 https://ec.europa.eu/info/sites/default/files/slides_the_wa_explained.pdf.
} 
lion European Union citizens and the 1 million UK citizens who had exercised free movement, in both directions, taken life choices, and believed that free movement was going to last forever. ${ }^{19}$ The whole Second Title of the agreement was devoted to protecting these citizens' rights.

The TCA has a very different aim. As its title states, its main objective is to achieve effective trade between the European Union and the UK, with zero tariffs on goods and zero quotas. ${ }^{20}$ Fish stocks are also very important in the agreement. ${ }^{21}$ The services market is mentioned regarding very limited mutual access in certain specific sectors. Citizens' rights are only of tangential importance in the agreement. From a social point of view, the TCA refers only to certain labour and social standards, which cannot be lowered. ${ }^{22}$ The reciprocal commitment to maintenance of the socalled "level playing field" guarantees that the trade deal, is not undermined. Workers are thus indirectly protected to prevent either party from gaining any commercial advantage. They are seen only as part of business costs.

Regarding mobility, as will be shown in more detail, some European Union and UK citizens and their family members can continue to live, work or study in their host country under the protection of the WA. For instance, British citizens and their family members can continue residing and working in the host Member State where they have already resided or worked, and where they may not be discriminated against, direct or indirectly, on grounds of nationality. In return, European Union citizens who resided in the UK when the agreements entered into force, have the same rights. The system of rights and requirements set out in Free Movement Directive 2004/38/EC is replicated, but there is no free movement for UK citizens within the European Union. They keep their rights only in one host Member State. Therefore, a British national authorised to maintain his temporal residence in Spain does not have the right to move to France and enjoy equal treatment there. Beside, the WA provides lifetime protection (there is no 'expiry date') and largely maintains the status quo for those citizens who had exercised their free movement right before the end of 2020. If they maintain their residence or working rights, they are kept in a kind of a "bubble".

As will be seen, the UK refused to include a chapter on mobility in the TCA agreement, so those EU citizens not covered by the WA are considered third country nationals in the UK. The same applies to UK citizens in the European Union. They are subjected to aliens and immigration Law. The only exception is the right to temporary

\footnotetext{
${ }^{19}$ From a Spanish perspective there was great interest in reaching a deal after Brexit. Spain has the largest number of UK nationals residing in any Member State (more than 350,000 live on our coasts, most of them pensioners).

${ }^{20}$ This aspect is underlined by UK Government "this ambitious Agreement - carefully judged to benefit everyone - is the first the EU has ever reached allowing zero tariffs and zero quotas. We will preserve the immense benefits of free trade for millions of people in the United Kingdom and across Europe" UK Government [22], p. 5.

${ }^{21}$ According to the Financial Times, the word fish appears 368 times in the document https://www.ft.com/ content/cc6b0d9a-d8cc-4ddb-8c57-726df018c10e.

${ }^{22}$ I am referring to fundamental rights at work, occupational health and safety standards, fair working conditions and employment standards, information and consultation rights at company level or restructuring of undertakings. See Chapter VI of the TCA on labour and social standards (Article 386 et seq.).
} 
intra-corporate transferees for providing a service, that is, for business purposes (the so-called mode 4).

Regarding social security coordination, the WA allows continuing to apply European Union coordination regulations to those citizens (EU and UK nationals and their family members) who maintain the residence status they gained before Brexit, and to their family members. Even European Court of Justice case-law and Administrative Commission decisions and recommendations are expressly included in a list under the WA to be considered.

For citizens (EU and UK nationals and their family members) outside the scope of application of the WA, there is a coordination protocol in the last 247 pages under the TCA agreement. This broadly follows the content of the European Union coordination regulations although there are some significant differences that will be pointed out in the last part of this article, showing that the TCA Protocol is significantly less protective.

The governance of the agreements does not coincide either. The WA is directly applicable under the supervision of national courts. Citizens can rely directly on the provisions contained or referred to in the Agreement (European Union coordination regulations) if they have direct effect under Union law. Further, UK Courts may request preliminary rulings from the EU Court of Justice for the first eight years. ${ }^{23}$

The implementation of the TCA, in contrast, is supervised by a joint body created by the European Union and the United Kingdom, the so-called Partnership Council. It envisages the future existence of several specialised committees, including a social security coordination one. ${ }^{24}$ Any dispute arising in this area will be first subjected to good faith consultation. If that does not work, an independent arbitration tribunal is envisaged, so the EU Court of Justice does not play any role in supervising the application of the TCA. ${ }^{25}$

Finally, there were also differences regarding Gibraltar, a very relevant issue from Spain's perspective as there are more than 15.000 Spanish frontier workers in that territory. ${ }^{26}$ Gibraltar is expressly covered by the WA and there is an ad hoc protocol for solving certain problems.

\footnotetext{
${ }^{23}$ See Article 158 of the WA.

${ }^{24}$ The first meeting of the Specialised Committee on Social Security Coordination took place in London the 6 July 2021.

25 "Both parties can engage in cross-sector retaliation in case of noncompliance with arbitration rulings (through suspension of obligations, including imposition of tariffs). This cross-sector retaliation applies across the economic partnership" Fella et alii. [8], p. 4.

${ }^{26}$ Gibraltar is not part of the UK; it is a colony of the British Crown. Union law has been applicable to Gibraltar to the extent provided for in the 1972 Act of Accession only by virtue of Article 355(3) TFEU. Gibraltar citizens are British nationals, but they do not have British citizenship so that, in principle, they did not have the right to move and reside freely within the territory of the Member States, including the right to enter the territory of the Member States without a visa or equivalent formalities (see Article 21 TFEU and Directive 2004/38). However, considering the "reciprocity mechanism" with all the EU Member States, and following a procedure monitored by the Commission, Gibraltar has been included in Annex II which lists those third countries whose nationals are exempt from visa requirements when crossing the external borders of the EU (Regulation (EU) 2018/1806 amended by Regulation (EU) 2019/592). Since Gibraltar is included in Part 3 of Annex II, its citizens are treated as other 'British Overseas Territories citizens (BOTC).
} 
The TCA, in turn, does not apply in Gibraltar, nor does it have any effects on its territory. For this reason, Spain and the UK discussed a framework for Gibraltar's future relationship with the European Union and agreed on it. ${ }^{27}$ Logically, it must be in conformity with European Union law, with the so-called "acquis Communautaire". At the time of writing, the Commission is currently working on a draft negotiation mandate, which will be proposed to the Council for a future EU-UK agreement on Gibraltar. On 25 December 2020, the Commission adopted its proposal for a regulation on the Brexit Adjustment Reserve. ${ }^{28}$ Under the Reserve, funding can be provided for national schemes aimed at assisting businesses and local communities adversely affected by the withdrawal, supporting the most affected economic sectors and employment. Campo de Gibraltar, the Spanish area close to Gibraltar, could potentially benefit from this support. ${ }^{29}$ In the meantime, Spain has adopted, and even extended, transitional internal regulations based on reciprocity. ${ }^{30}$

\section{Mobility under the WA}

Regarding mobility under the WA, the most important issue seems to be identifying who falls within the scope of application of the Agreement. ${ }^{31}$

\subsection{Pre-Brexit citizens covered by the WA}

As has been mentioned, the WA aims to protect so-called "pre-Brexit citizens", in other words, European Union and UK citizens, employees, self-employed workers, and pensioners, who were in a cross-border or transnational situation - between the UK and the European Union - on 31 December 2020. There are two requirements.

1. Before that date, those persons should have $\operatorname{had}^{32}$ residence rights under the national law of the host State, transposing free movement Directive 2004/38/EC or rights to work under the European Union Law. (Arts. 45 and 49 TFEU are also directly applicable).

2. Secondly, they must maintain that situation - "their right to reside or work" - in the host Member State after that date.

\footnotetext{
${ }^{27}$ See, in extenso, Ribes Moreno [18].

${ }^{28}$ Its aim will be to support the adverse consequences of Brexit and to mitigate the impact on the economic, social, and territorial cohesion.

${ }^{29} \mathrm{https} / / /$ eur-lex.europa.eu/legal-content/EN/TXT/?uri=CELEX:52020PC0854.

${ }^{30}$ See Royal Decree-law 38/2020 https://www.boe.es/eli/es/rdl/2020/12/29/38. Some measures regarding Gibraltar, not affected by the TCA, were extended for four months, until the end of October 2021, see Order PCM/648/2021 https://www.boe.es/eli/es/o/2021/06/23/pcm648.

${ }^{31}$ At this regard, see -comparing the situation under the WA and under the TCA- García de Cortázar y Nebreda [11]. Regarding the WA, see Gardeñes Santiago [12]. I agree with those authors that regarding mobility and social security rights under the WA, the Commission Guidance Note on the WA issued in May 2020 must be consulted even though it is a non-binding document and does not reflect the official position of the Commission. It was drafted by the Commission's staff and is full of clarifying examples. https://ec.europa.eu/info/sites/default/files/brexit_files/info_site/c-2020-2939_en.pdf.

${ }^{32}$ It must be kept in mind that EU law residence status is granted automatically if all conditions of the EU law are fulfilled, even if administrative requirements have not been met.
} 


\begin{tabular}{|c|c|c|}
\hline & WA pre-Brexit citizens & TCA post-Brexit citizens \\
\hline Negotiated & 2 years and 7 months & 11 months \\
\hline \multirow[t]{2}{*}{ Signed } & $17-10-2019^{a}$ & 24-12-2020 (in extremis) \\
\hline & $\begin{array}{l}\text { (*) Decision 2020/135 EUOJ } \\
\text { L 29, 31-1-2020 }\end{array}$ & $\begin{array}{l}\text { (*) Definitive version Decision } \\
\text { 2021/689 EUOJ L } 149 \text { of } \\
30-4-2021\end{array}$ \\
\hline \multirow[t]{3}{*}{ In force } & $1-2-2020^{b}$ & $1-1-2021$ \\
\hline & $\begin{array}{l}\text { (*) transition period until } \\
31-12-2020 .\end{array}$ & \\
\hline & $\begin{array}{l}\text { In practical terms, in force } \\
\text { since } 1-1-2021\end{array}$ & \\
\hline Length/pages & 177 pages & 2,500 pages \\
\hline Objective & $\begin{array}{l}\text { Protect who have used FMW } \\
\text { before } 1-1-2020 \text { and had a } \\
\text { right to reside/work that } \\
\text { remains there thereafter }\end{array}$ & $\begin{array}{l}\text { Trade, fish stocks, only social } \\
\text { security coordination... }\end{array}$ \\
\hline \multirow[t]{3}{*}{ Mobility } & No FMW & No FMW \\
\hline & $\begin{array}{l}\text { Maintenance of residence and } \\
\text { work rights in host State. }\end{array}$ & $\begin{array}{l}\text { TCN status (aliens and } \\
\text { immigration laws) }\end{array}$ \\
\hline & $\begin{array}{l}\text { No discrimination on } \\
\text { nationality grounds }\end{array}$ & $\begin{array}{l}.-(*) \text { free travel } 90 / 180 \\
\text {--Short term work } \\
\text {-- professional intra-company } \\
\text { temporary transfers (mode } 4)\end{array}$ \\
\hline Social Security & EU coordination Regulations & $\begin{array}{l}\text { TCA Protocol on SSC } \\
247 \text { pages }\end{array}$ \\
\hline EU Law logic & Yes & No \\
\hline Court of Justice role & Yes & No \\
\hline Gibraltar & Covered & No covered \\
\hline $\begin{array}{l}\text { Recognition of } \\
\text { professional qualifications }\end{array}$ & Yes & No \\
\hline
\end{tabular}

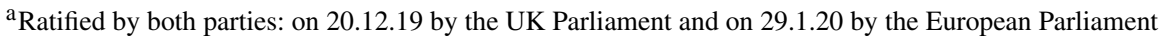

$\mathrm{b}_{31}$ December at 23.00 in Britain and 24.00 in Brussels

For UK nationals, the host State is an EU Member State, but only one State. For European Union nationals, the host State is always the United Kingdom. It must be considered that the WA also referred to their "core" family members, and their "extended family" defined by that Directive.

Some examples of persons who are within the scope of application of the WA may be referred to: (a) a British national who was working and living in Prague before 31.12.2020 and continues living and working there after that date; (b) a Spanish frontier worker living in Cadiz and working in Gibraltar before that date and who continues working there; or (c) a British national who was residing in Bratislava and 
working in Austria and Hungary as a frontier worker before Brexit and maintains his or her status. In this last case, there is only one host Member State - the State where this person resides.

In any case, persons under the scope of application of the WA can maintain that situation and must not suffer any discrimination on the grounds of nationality. Furthermore, any professional qualification recognised before the transition period will still be valid. ${ }^{33}$

\subsection{Citizens falling outside the personal scope of the WA and posted workers}

Once we have defined who comes within the WA, we must make reference to those who fall outside the personal scope of the WA. We could mention the following persons: ${ }^{34}$

1. EU citizens and UK nationals whose rights in the host State at the end of the transition period are based on the sole fact that they were citizens of the Union as defined in Article 20 TFEU fall outside the scope of the Agreement. For instance, a UK minor covered by the Ruiz Zambrano case ${ }^{35}$ does not fall within the WA. However, if they were in a transnational situation, they could be covered by the WA. For example, whether they have exercised their free movement right, as happened in Chen case. $^{36}$

2. Returning European Union or UK citizens coming back to the State of which they are nationals after exercising free movement rights ${ }^{37}$ also fall outside the scope of the WA. Their situation will be regulated by UK or by EU law, respectively.

Finally, as regards posted workers - for instance, a British worker posted to Spain from May 2019 for 2 years - it must be highlighted that the WA does not protect

\footnotetext{
${ }^{33}$ See Article Directive 2005/36/EC and for instance Directive 98/5/CE regarding lawyers.

${ }^{34}$ In extenso, Gardeñes Santiago [12], p. 9 et seq.

35 Judgement on case C-34/09 Ruiz Zambrano. ECLI:EU:C:2011:124. According to the EUCJ (Grand Chamber) "citizenship of the Union requires a Member State to allow third country nationals who are parents of a child who is a national of that Member State to reside and work there, where a refusal to do so would deprive that child of the genuine enjoyment of the substance of the rights attaching to the status of citizen of the Union". This requirement applies even when the child has never exercised his right to free movement within the territory of the Member States" https://curia.europa.eu/jcms/upload/docs/ application/pdf/2011-03/cp110016en.pdf.

${ }^{36}$ Judgement on case C-200/02 Zhu y Chen, ECLI:EU:C:2004:639. In this important judgment, the EUCJ, sitting as a full Court, had to decide about a minor and her family residence rights in the UK. Mrs Chen took up residence in the island of Ireland in order to enable the child she was expecting to acquire Irish nationality and, consequently, to enable her to acquire the right to reside, should the occasion arise, with her child in the UK. According to the EUCJ, this minor holding an Irish passport and exercising her right to free movement, has the right to reside for an indefinite period in the UK once the requirements of the FMW Directive are fulfilled. This was the case, as the minor was covered by appropriate sickness insurance and was in the care of a parent who was a third country national having sufficient resources for that minor not to become a burden on the public finances of the host Member State (UK). In such circumstances, those same provisions allow a parent who is that minor's primary carer to reside with the child in the host Member State.

${ }^{37}$ Judgement on case C-370/90 Singh, ECLI:EU:C:1992:296 or case C-234/97 Fernández Bobadilla, ECLI:EU:C:1999:367.
} 
freedom to provide services, nor give a right to such workers to stay in the host country, whether they rely only on their capacity as posted workers, their right of residence in the host State loses their main legal basis. ${ }^{38}$ However, when they are UK or EU nationals it cannot be ruled out that they may qualify as beneficiaries of the WA on other grounds (provided for in Article 13 WA). ${ }^{39}$ For instance, they could base their application on their UK or EU citizenship (with sufficient resources and comprehensive healthcare insurance), on being students or even, controversial though it may be, on their condition of workers. ${ }^{40}$ Obviously, if the posted workers also carry out another professional activity in the host State, they will be covered by the WA. ${ }^{41}$

\subsection{Some key points about pre-Brexit citizens under the WA}

a) Pre-Brexit citizens do not need to be permanent residents in the host Member State in order to be covered under the WA, even if the person was temporarily outside the host State on 31 December 2020. Under European Union law, some absences are allowed without the right to reside being lost. For instance, a person who has a permanent right to reside only loses his right after years of absence. ${ }^{42}$ In case of temporary residence, the maximum absence envisaged by the Directive is 6 months per year. ${ }^{43}$

b) The right of residence could have been acquired directly before the end of the transition period. A British citizen who moved to Spain in December 2020 as a jobseeker could continue looking for a job after the end of the transition period under Article 45 TFEU. ${ }^{44}$

c) The WA also applies to inactive citizens, such as pensioners or students, if they maintain their right to reside in the host Member State. For example, a Czech citizen studying in Oxford who wants to continue doing so, will maintain her rights under the umbrella of the WA, for example, the right to pay the same tuition fees as British students. Obviously, inactive citizens under the WA must continue complying with the temporal residence criteria envisaged in European Union Law (see

\footnotetext{
${ }^{38}$ See page 4 of European Commission [6].

${ }^{39}$ García de Cortázar y Nebreda [11].

${ }^{40}$ Consider that the Recital fifth of the Preamble of the Regulation on free movement of workers (Regulation EC/492/2011) states that "Such right should be enjoyed without discrimination by permanent, seasonal and frontier workers and by those who pursue their activities for the purpose of providing services".

${ }^{41}$ See European Commission [6], p. 4.

${ }^{42}$ See second paragraph of Article 11, referring to the five-year rule of Article 15(3) of the WA. As an example, EU citizens who acquired the right of permanent residence in the host State in accordance with Directive 2004/38/EC and left the host State four years before the end of the transition period are to be considered as "exercising their right of residence in accordance with Union law" (even if they do no longer have the right of permanent residence under Directive) at the end of the transition period because they have not been absent for a period exceeding five consecutive years. They are eligible for the new permanent residence status in the host State, provided they apply within the deadline set out in the first subparagraph of Article 18(1)(b) of the WA.

${ }^{43}$ Consider first paragraph of Article 11 of the WA, referring to continuity of residence rules under Article 15(2) of the WA, which mirrors Article 16(3) of Directive 2004/38/EC.

${ }^{44}$ Regarding a possible expulsion, article 14 (4)(b) of the Free Movement Directive and old C-292/89 Antonissen case ECLI:EU:C:1991:80, could be considered.
} 
Article 7 of Directive 2004/38) i.e., the requirements of having sufficient resources and comprehensive healthcare insurance. The WA is just a mirror so we could have the same problems we used to have under European Union law which arguably has a problem of "aporophobia", ${ }^{45}$ reflecting a kind of aversion to the mobility of poor European Union citizens and their access to social assistance. ${ }^{46}$

d) As regards third country nationals' family members, they will keep their derived rights in the host State, so they will have the right to work there. Children born after the end of the transition period will also be under the WA.

e) Further, it must be kept in mind that the pre-Brexit citizens, persons within the scope of the WA, can change their status and still be covered by the said agreement, although there are some limitations. For example, a student can become a worker, or a self-employed person can become a pensioner and still be covered by the agreement. $^{47}$

\subsection{Implementation of the WA in European Union Member States and in the UK}

Regarding residence status of the pre-Brexit citizens the host State must make a choice between these two options: ${ }^{48}$

1. To operate a constitutive residence scheme: where beneficiaries acquire residence status only if they make an application and the host state authorities grants this application.

2. Alternatively, to follow a declaratory residence scheme: where the new residence status will be granted automatically if all conditions of the WA are fulfilled. This is the system followed under European Union free movement rules regarding residence status even if administrative requirements have not met.

The United Kingdom has chosen a constitutive residence scheme, the so-called European Union Settlement Scheme or EUSS, ${ }^{49}$ that gives "settled status" whether the applicant had permanent residence under European Union law and a "pre-settled status" if the person has not reached five years of previous temporary legal residence. The 'grace period' (giving rise to a kind of cliff-edge deadline) for applying until the end of June 2021 (six months after the transition period) is now over. According to the most recent data, more than five million citizens have applied to the EUSS and it seems that more could have done so. It has not been clarified what could be

\footnotetext{
${ }^{45}$ This is a neologism created by a renowned Spanish philosopher (Adela Cortina) in the 90's to describe

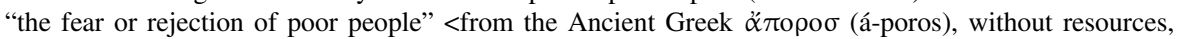
indigent, poor, and $\varphi o ́ \beta \sigma \sigma$ (phobos), fear)>. In other words, it is the disgust and hostility toward poor people, without resources or who are helpless.

${ }^{46}$ Topic that has produced lots of tensions reflected in "popular" judgments of the European Court of Justice (cases Brey C-140/12, ECLI:EU:C:2013:565, Dano C-333/13, ECLI:EU:C:2014:2358, Alimanovic C-67/14, ECLI:EU:C:2015:597 ... and finally, the already mentioned in this article, case C-308/14 Commission vs the UK, ECLI:EU:C:2016:436). See about all this case-law and its practical consequences in Spain, Carrascosa Bermejo [3].

${ }^{47}$ But you cannot become persons referred to in points (a) to (d) of Article 10 of the WA.

${ }^{48}$ See Article 18 of the WA.

${ }^{49}$ https://assets.publishing.service.gov.uk/government/uploads/system/uploads/attachment_data/file/ 988540/main-euss-guidance-v12.0-gov-uk.pdf.
} 
a reasonable ground for not having applied in time ${ }^{50}$ and whether there will be a plan B for those concerned. ${ }^{51}$ From 1 July 2021, European Union citizens granted settled status under the EU Settlement Scheme will need to evidence their rights (for applying for a job or renting a property) in the United Kingdom with their digital immigration status, rather than with their passport or ID card. ${ }^{52}$

According to information provided by the Commission, ${ }^{53}$ using different time frames, fourteen Member state have also chosen a constitutive residence scheme, ${ }^{54}$ while the others operate a declaratory system. ${ }^{55}$ Although Spain opted for a declaratory system, the Government recommends, in a Spanish "Brexit guide", that beneficiaries of the WA obtain the new residence document. This is a physical card containing biometric elements that can ease administrative formalities in Spain for the holder and even the crossing of the external borders of the European Union. ${ }^{56}$

The beneficiaries of the WA have the right to cross the borders of the host State once they provide evidence of being a beneficiary of the Agreement. Holders of these specific kind of documents will therefore be exempted from any exit or entry visa or equivalent formality. ${ }^{57}$

The WA also establishes that the State which is the place of work must issue a document certifying the status of frontier workers covered by the WA if they request it, even if not during a period of employment. ${ }^{58}$ It has been clarified that this type of document does not grant a new residence status, but rather only recognises a preexisting right to work in this State (or in various States) which continues to exist. With this document, frontier workers can leave and re-enter the State of work without any problems.

\section{Social security coordination under the WA}

As regards social security under the WA, there are some privileged citizens who can rely on European Union coordination Regulations. ${ }^{59}$ The personal scope of this protective measure is much broader than the mobility part and has its own concepts and

\footnotetext{
${ }^{50}$ https://www.gov.uk/settled-status-eu-citizens-families/eligibility.

${ }^{51}$ See Boswel and Patel [1]. A critic point of view in Thomas [21].

${ }^{52}$ See page 2 of the $4^{\text {th }}$ Joint Report "on the implementation of residence rights under part two of the WA" issued by the specialised Committee on citizens' rights, the 17 June 2021.

53 https://ec.europa.eu/info/sites/default/files/overview_ms_residence_rights.pdf.

${ }^{54}$ Belgium, Denmark, France, Latvia, Luxembourg, Hungary, Malta, The Netherlands, Austria, Romania, Slovenia, Finland, and Sweden.

${ }^{55}$ Czechia, Germany, Estonia, Ireland, Spain, Croatia, Italy, Cyprus, Lithuania, Poland, Portugal, and Slovakia.

${ }^{56}$ Much better than the former registration certificate in Spain, which is a simple sheet of paper https:// www.lamoncloa.gob.es/brexit/preparacion2/Paginas/271218_residenciatrabajo.aspx.

${ }^{57}$ In the sense of Article 4(2) and the second part of Article 5(1) of Directive 2004/38/EC; i.e., electronic travel authorisation.

${ }^{58}$ See Article 26 of the WA.

${ }^{59}$ Regulation (EC) 883/2004 and Regulation (EC) 987/2009.
} 
logic. For instance, as is the case under the coordination Regulations, the WA protects not only EU and UK citizens, but also stateless persons and refugees habitually residing in the European Union or the UK, and even third country nationals legally residing there, are protected. The WA also applies to family members and survivors of the above categories, who do not have to be in a cross-border situation.

Simplifying, we can find two different situations under the WA, depending on whether the coordination Regulations are applied in full or in part.

In the first situation, regarding persons who rely on whole coordination Regulations, we can find those that are in a "social security cross-border situation involving the UK and an EU Member State" that continues to apply. ${ }^{60}$ Again, it is necessary that the situation concerned remains unchanged or the persons continue to be in their transnational situation. This international situation, involving both the UK and an EU Member State at the same time without interruption, could be referred not only to social security applicable legislation, also to the right of residence or even to mere right to work in the counterpart State. Some examples of these type of situations are the following: on the one hand, a Czech citizen, habitually residing in the Czech Republic, working in the UK, and returning home every week who is subjected to UK Social Security legislation and continues in this way. ${ }^{61}$ On the other hand, we might find a UK national who receives an old-age pension from the UK and habitually resides in Spain whose sickness benefits-in-kind are granted by UK. ${ }^{62}$ Finally, we might find a Moroccan citizen, legally residing in the Czech Republic and working in the UK, subjected to the UK legislation according to previously applicable old coordination Regulations $^{63}$ as a consequence of Regulation EEC/859/2003. ${ }^{64}$ Once the transnational situation with the UK/EU finishes, the WA, and the whole application of the regulations ends. For instance, where a Czech citizen exporting UK unemployment benefits to the Czech Republic, finds a job in the Czech Republic and establishes her habitual residence there.

Secondly, there will be persons to whom only part of the coordination Regulations rules, for instance aggregation of periods, continues to apply, or become applicable in the future due to specific circumstances. ${ }^{65}$ This could be the case with, for example, a Czech citizen who worked in UK for three years (2014-2017) and in 2025, retires and receives a UK pension under the Regulations. ${ }^{66}$ If he dies in 2026 his spouse would be entitled to UK survivor's benefits based on the UK legislation and the coordination regulations which could be exported to the Czech Republic without any reduction.

Finally, some doubts arise regarding the posting of workers under the WA. It seems that a posting started before the end of the transition period can continue until the end of the posting period envisaged, and Portable Document A1 could be valid for this

\footnotetext{
${ }^{60}$ See Article 30 of the WA.

${ }^{61}$ See Article 11(3)(a) of Regulation (EC) 883/2004.

${ }^{62}$ Article 11(3)(e) of Regulation (EC)883/2004.

${ }^{63}$ Article 13(2)(a) of Regulation (EEC)1408/71.

${ }^{64}$ The UK did not take part in the adoption of Regulation (EU) 1231/2010 that allows to apply in force coordination regulations to Third Country Nationals.

${ }^{65}$ See Article 32 of the WA.

${ }^{66}$ See Article 32(1)(a) of the WA.
} 
period. For instance, one may think about a UK national posted to Spain before 2021 and whose posting ends in 2022. In this case, is their Portable Document A1 in force until its validity expires? It is true that there is no freedom to provide services under the WA, but it could be understood it is covered by the first mentioned situation. ${ }^{67}$ If it is under the WA, they could even seek an extension of Portable Document A1, under Article 16 of the Regulation (EC) 883/2004, before the transitional period ends. Curiously enough, it seems that such an extension beyond the transitional period has been agreed between the institutions of European Union Member States and the relevant UK institution (specifically, Her Majesty`s Revenue and Customs) before the end of the transition period. For instance, in the case of Airbus employees these extensions guaranteed by Spanish social security administration (Tesorería de la Seguridad Social) could go on until 2025. ${ }^{68}$ These extensions can be controversial, because the Commission understood that since the transition period finished on 31 December 2020, a new posting period in order to provide services (e.g., to send a construction worker to the UK or vice versa) is no longer possible within the framework of the WA. From Commission's perspective it seems that the only possible posting covered by the WA would be the kind not related to provision of services (e.g., training in another member State). ${ }^{69}$

\section{Mobility under the Trade and Cooperation Agreement}

As has been mentioned before, the TCA does not regulate mobility, due to the opposition of the UK. It does not refer to the rights to enter, stay, reside, or work in the counterpart. For this reason, all movements after January 2021 of persons outside the scope of application of the WA, will be subjected to the immigration legislation applicable to third country nationals of the European Union Member States or the UK, respectively. As we will see the only exception envisaged to this are the temporary intra-corporate transferees envisaged in the TCA.

However, the European Union and the United Kingdom have mutually agreed to allow short-stay visa-free visits of up to 90 days within any 180-day period. Beyond 90 days, the applicable national legislation would apply. The UK, for its part, has stated that will be flexible regarding short-stay visas of less than 180 days. $^{70}$

Regarding inactive persons, including pensioners, national regulations will apply. That could include asking for a visa and facing stricter controls for testing sufficient resources to allow residence rights. Nevertheless, under Directive 2003/109/EC concerning the status of third-country nationals who are long-term residents Britons would gain a similar status to that of EU nationals who have remained five years in

\footnotetext{
${ }^{67}$ See Article 30(1)(e) of the WA.

${ }^{68}$ García de Cortázar y Nebreda [11].

${ }^{69}$ See the example included on page 28 of the EU Commission Notice on the WA, referred to a posted worker that will be covered by WA Article 30(1)(e) as he is not providing a service. In particular, the example was referred to a Croatian citizen sent to the UK for a 6-months training ending after the end of the transition period (subject to the Croatian legislation based on Article 12 of Regulation (EC) No 883/2004).

${ }^{70}$ García de Cortázar y Nebreda [11].
} 
a Member State. Again, EU legislation which has protected third-country nationals from the time of the Tampere European Council in 1999, ${ }^{71}$ works in favour of British nationals. It does not really matter what could happen to an EU pensioner who wants to move to the UK because, if the truth be told, there probably are not many of these.

Regarding work permits, some issues must be considered:

1. The simplified and almost automatic system of recognition of professional qualifications no longer exists, so national law on this topic will apply. However, the TCA envisages that the European Union and the UK may reach additional agreements in the future on this topic, on a case-by-case basis and for specific professions. The UK is mainly interested in the health professions, not having enough national workers in that important sector.

2. The only exception regarding labour mobility envisaged in the TCA concerns temporary posting of intra-corporate transferees for business purposes ('mode 4', to use the terminology of the World Trade Organisation). These workers will be granted a special "intra-company visa" that allows them to enter, stay and be employed in the parent or subsidiary company for a maximum of three years, in the case of managers and specialists, and one year, in the case of trainees. Posted employees must have been previously employed by the sending company (for one year in the case of managers and specialists and for six months in the case of trainees). Eligible applicants do not need to satisfy the English language requirements, but they do need to meet the minimum salary threshold. ${ }^{72}$ This mode 4 foreseen in the TCA is very similar to what is laid down in Directive 2014/66/EU of 15 May 2014 regarding the conditions of entry and residence of third-country nationals in the framework of an intra-corporate transfer. ${ }^{73}$

In any event, Member States cannot give more favourable treatment to undertakings established in the United Kingdom (or any other third country) than to companies established in the European Union that have to comply with the growing requirements of the anti-dumping Posted Workers Directive 96/71/EC (as amended by Directive (EU) 957/2018).${ }^{74}$ As usual, the Posted Workers Directive is applicable by EU undertakings that are posting UK nationals legally residing in a European Union Member State in order to provide a service in another European Union Member State. ${ }^{75}$ For instance, a United Kingdom national, with a pre-Brexit status in Spain under the WA, and allowed to work in Spain, could be posted by a Spanish undertaking to provide a service in France, without asking for a French job permit.

3. With the exception the so-called mode 4 , for any other worker, the respective national laws on aliens will apply. In the case of the United Kingdom, EU citizens who ask for a working visa will be subjected to the Point Basis System envisaged for any third country national. Obtaining a visa is conditional on reaching

\footnotetext{
${ }^{71}$ https://www.europarl.europa.eu/summits/tam_en.htm.

${ }^{72}$ This kind of visa does not provide a route to settlement in the UK.

${ }^{73}$ This Directive does not apply in Ireland or Denmark.

${ }^{74}$ See Directive 96/71 Article 1(4).

${ }^{75}$ See CJEU case-law: Vander Elst C-43/93, Commission vs Luxembourg C-445/03. European Commission [6], p. 2 and 3.
} 
70 points by having a job offer from an authorised company (worth 20 points), an adequate level of training (worth 20 points), a salary above 26,500 pounds sterling per year (worth 20 points) and an adequate level of English (B1, worth 10 points). There are other ways of obtaining a work visa, such as the health and care special visa, or the talent visa, for persons who can prove exceptional ability. Once authorised to work post-Brexit, workers would in practice enjoy similar rights to those of nationals, due to the existence of regulations enforcing equal treatment in many Member States ${ }^{76}$ as well as in European Union law ${ }^{77}$ and in UK law. ${ }^{78}$

\section{Social security coordination under the TCA}

The TCA includes an important Protocol on Social Security Coordination which, although it is very similar to the European Union coordination Regulations applicable to WA beneficiaries, is less protective. The shortcomings which have been detected are the following:

1. First, some of the most controversial benefits coming within European Union coordination regulations are not included in the material scope of the SSC Protocol of the TCA. The excluded benefits are, firstly, family benefits. It must be recalled, those were the benefits referred to in the previously mentioned case C-308/14 Commission v United Kingdom. ${ }^{79}$ Secondly, the so-called special non-contributory cash benefits (SNCB) - a mixed type of benefit with a nature between that of social assistance and social security and which is non-exportable. These excluded benefits are listed in a specific Annex of the Protocol and as can be seen there, many of them are linked with disability, which may pose a problem for the specific protection of these persons. ${ }^{80}$ Thirdly, long-term care benefits, that are coordinated as sickness benefits under the EU coordination Regulations in force ${ }^{81}$ are also out of the material scope of the TCA. Finally, the exotic "payments to meet expenses for heating in cold weather" are also excluded. $^{82}$

Furthermore, it must be taken into account that within the healthcare benefits some specific coverage is expressly excluded under the TCA: in particular, the expensive assisted conception services.

In this regard, it must be underlined that a specialised committee under the TCA on the SSC, among its other powers, can amend the Annexes and Appendices to the Protocol.

\footnotetext{
${ }^{76}$ See in Spain Alien Law LO 4/2000. https://www.boe.es/eli/es/lo/2000/01/11/4/con.

${ }^{77}$ See Directive 2011/98/EU.

${ }^{78}$ Discrimination is prohibited on many grounds but not on the basis of nationality. See British Equality Act 2010. https://www.legislation.gov.uk/ukpga/2010/15/contents.

${ }^{79}$ ECLI:EU:C:2016:436.

${ }^{80}$ See Part 1 of Annex SSC-1 of the Protocol.

${ }^{81}$ They are defined in Article SSC.1 (r) and are listed in part 2 of Annex SSC1 of the Protocol.

${ }^{82}$ They are listed in Part 3 of Annex SSC.1 of the Protocol, and they are certainly strange, at least for the Spanish social security system.
} 
2. Secondly, there are restrictions on the exportation of some benefits under the SSC Protocol of the TCA. ${ }^{83}$ On the one hand, it is not possible to export unemployment benefits. Under the EU coordination Regulations is possible to export such benefits - provided certain requirements are fulfilled - for three months, with a possible extension for another three months. The export of this contributory cash benefit has always been controversial, not only because social security administrations want to monitor beneficiaries and promote their employability, offering jobs or training to them, but also because, given the wage differences between Member States, it is possible that the recipient of high unemployment benefits may find the wages of a destination state with a lower standard of living unattractive.

On the other hand, the exportation of invalidity benefits in general is not envisaged under the TCA, disregarding their contributory or not-contributory nature. This is a shocking restriction, a major change from the coordination Regulations, which generates a serious lack of protection for migrants. For example, in the event of an accident at work, a EU migrant will not be able to return to his/her country of origin and receive his or her UK invalidity pension there. It seems that EC requested the continuation of invalidity exportation, but the UK refused to maintain the status quo. In any case, the UK position seems surprising, as many bilateral social security agreements signed by the UK with other third countries do provide for the export of invalidity benefits. ${ }^{84}$

3. Thirdly even it is not envisaged that there be any freedom to provide services under the TCA, the SSC Protocol provides a special 'rule of conflict of laws ${ }^{\text {}}{ }^{85}$ that allows the maintenance (for 24 months) of insurance under the social security law of the home State. ${ }^{86}$ This provision seems to copy posting provisions envisaged under Regulation EC/883/2004 Article 12.

The United Kingdom and all EU Member States have applied this provision since January 2021. ${ }^{87}$ After some uncertainty, ${ }^{88}$ the EU has notified the UK that the 27

\footnotetext{
${ }^{83}$ See Article SSC.8.(b) of the Protocol.

${ }^{84}$ See García de Cortázar y Nebreda [11], which mentions in this regard as envisaging the exportation of invalidity benefits, the bilateral social security agreements signed between the UK and Barbados, Israel, Jamaica, Jersey and Guernsey, the Republics of ex-Yugoslavia, the Philippines, Turkey, and the USA.

${ }^{85}$ The rules for determining the national social security law applicable are not actual "rule of conflict of laws" in a technical legal sense. Social security law is Public Law, and it is not possible to apply a foreign social security law before the court of another nationality. That assertion does not preclude the existence, of assimilation of conditions (equal treatment of facts or events) including the aggregation of foreign contributions. Carrascosa Bermejo [4], p. 150 et seq.

${ }^{86}$ See Article SSC. 11.

${ }^{87}$ See page 54 of EUOJ C-55 of 16 February 2021 on Notification by the European Union made in accordance with the Trade and Cooperation Agreement between the European Union and the European Atomic Energy Community, of the one part, and the United Kingdom of Great Britain and Northern Ireland, of the other part https://eur-lex.europa.eu/legal-content/EN/TXT/PDF/?uri=OJ:C:2021:055:FULL\&from=ES.

${ }^{88}$ In a previous notification under the so-called Category A, only Austria, Hungary, Portugal and Sweden were mentioned as having expressly agreed to apply this special rule. The other $23 \mathrm{EU}$ states fell under category $\mathrm{C}$, as they had not indicated whether or not they wish to derogate from general rules (See Article SSC.10). https://eur-lex.europa.eu/legal-content/ES/TXT/?uri=uriserv\%3AOJ.L_.2020.444.01.1486. 01.SPA\&toc=OJ\%3AL $\% 3 \mathrm{~A} 2020 \% 3 \mathrm{~A} 444 \% 3 \mathrm{ATOC}$.
} 
Member States fall within the Category $\mathrm{A}^{89}$ in accordance with Article SSC.11(2) on detached workers, so they wish to derogate from the lex loci laboris general rule included in Article SSC.10. Everything will be clearer once the Annex of the Protocol will be published with all Member States on the list.

Linked to the posting issue, it is important to underline that there is no rule in the SSC Protocol providing national administrations flexibility in the application of the rules of conflict fixing the national social security law applicable. ${ }^{90}$ In other words, the TCA lacks a provision equivalent to Article 16 (1) of the EU basic coordination Regulation ${ }^{91}$ which, among other things, allows for agreements between national administrations for the extension of the posting of workers beyond 24 months.

Some States might wish to negotiate a bilateral agreement or convention with the UK to that effect. However, this does not seem possible on this topic. The SSC Protocol forbids unequal treatment between Member States. ${ }^{92}$ Article 7 of Decision (EU) 2021/689 allows bilateral agreements on social security with the UK - but not covering matters already dealt with by the TCA. ${ }^{93}$ It might be the case as regards the determination of the applicable law that this is entirely covered by the Agreement. In any case, exceptions or some flexibility regarding the applicable law is needed and perhaps specific agreements under the umbrella of the social security Committee could be envisaged in this regard in the future.

4. Finally, the Protocol will be in force only for 15 years. After that, a new updated protocol can be negotiated. ${ }^{94}$ This limited duration seems very short for social security rights that, e.g., in the case of pensions, may take decades to be generated. The loss of validity of the Protocol after 15 years may lead to the very legal uncertainty that the Protocol itself seeks to avoid.

This article has underlined the negative side of the SSC Protocol in comparing it to EU coordination regulations. However, it is also possible to see the glass as being half full. In the 247 pages of the Protocol, many social security rights are protected in favour of post-Brexit citizens in a powerful way, in many cases more generously than under any other international social security agreement in force. For instance, as regards healthcare rights, scheduled and unscheduled healthcare is covered, and the European Health Insurance Card will continue to apply although the British health card will change its appearance, it will go on having the same function. The Protocol

${ }^{89}$ The 27 Member States expressed their wish to derogate from Article SSC.10 [General rules] TCA as of from 1 January 2021.

${ }^{90}$ See Regulation EC 883/2004 Article 11 to 15.

${ }^{91}$ Regulation EC 883/2004 Article 16 (1) "Two or more Member States, the competent authorities of these Member States or the bodies designated by these authorities may by common agreement provide for exceptions to Articles 11 to 15 in the interest of certain persons or categories of persons."

${ }^{92}$ See Article SSC.4 of the SSC Protocol under the TCA.

${ }^{93}$ The recitals 12 and 13 of the Preamble and Articles 7 and 8 of Decision (EU) 2021/689 OJEU L 149 of 30-4-2021 provides for bilateral agreements between EU Member States and the UK on social security. Obviously, those agreements must be compatible with the purpose of TCA and EU law and take into account the internal market and broader EU interests and not be contrary to the principle of nondiscrimination (Article 7 of the mentioned Decision). It also stipulates that the Commission must be an observer of those negotiations and must ultimately approve the outcome of them. https://eur-lex.europa. eu/legal-content/EN/TXT/PDF/?uri=CELEX:32021D0689\&from=FR.

${ }^{94}$ See Article SSC.70 of the SSC Protocol under the TCA. 
also provides for healthcare coverage for UK pensioners who decide to move to the European Union from 2021. Again, only a formal change is envisaged: the Portable Document $\mathrm{S} 1$ will be replaced by a new form.

\section{Conclusions}

As this article has shown, despite the substantial negotiating efforts made in the two complex international agreements negotiated (WA and TCA), Brexit will inexorably bring complications for the citizens affected. Protection is neither homogeneous nor simple, depending on whether we are dealing with the privileged citizens protected by the WA and those who fall under the new TCA. The first remain in a kind of bubble if they maintain their current transnational situation, the WA wants to preserve the status quo. The latter, in turn, will suffer significant gaps in their social rights whether they move to the counterpart state in the future, the TCA is clearly less protective than the coordination Regulations, but more protective that any other international social security agreement.

The loss of certain rights can be a great opportunity to appreciate what one used to have and to value the advantages of European Union membership, which can not be taken for granted.

Funding Note Open Access funding provided thanks to the CRUE-CSIC agreement with Springer Nature.

Open Access This article is licensed under a Creative Commons Attribution 4.0 International License, which permits use, sharing, adaptation, distribution and reproduction in any medium or format, as long as you give appropriate credit to the original author(s) and the source, provide a link to the Creative Commons licence, and indicate if changes were made. The images or other third party material in this article are included in the article's Creative Commons licence, unless indicated otherwise in a credit line to the material. If material is not included in the article's Creative Commons licence and your intended use is not permitted by statutory regulation or exceeds the permitted use, you will need to obtain permission directly from the copyright holder. To view a copy of this licence, visit http://creativecommons.org/licenses/by/ $4.0 \%$.

\section{References}

1. Boswel, C., Patel, C.: When the clapping stops. EU care workers after Brexit. The Joint Council for the Welfare of Inmigrants, January 2021

2. Carrascosa Bermejo, D.: Libre circulación de ciudadanos de la Unión Europea y su acceso a las prestaciones no contributivas (incluida la asistencia sanitaria): el impacto de la jurisprudencia del. Tribunal de Justicia. Revista del Ministerio de Empleo y Seguridad Social, n 127, pp. 195-226 (2017)

3. Carrascosa Bermejo, D.: Libre circulación de ciudadanos comunitarios inactivos y protección social ¿Sufre la UE de aporofobia? In: VVAA Miranda Boto, J.M. (Ed.) El Derecho del Trabajo español ante el Tribunal de Justicia: problemas. Cinca, Madrid, pp. 505-533 (2018)

4. Carrascosa Bermejo, D.: La coordinación comunitaria de los sistemas nacionales de Seguridad Social: Determinación de la Ley nacional aplicable. Reconocimiento y cálculo del derecho a una pensión de vejez contributiva. Universidad Carlos III. Enero 2003. http://hdl.handle.net/10016/11723

5. Dustmann, C., Frattini, T.: The fiscal effects of immigration to the UK. Econ. J. 124, F593-F643 (2014)

6. European Commission: Notice to Stakeholders. Withdrawal of the UK and EU rules on posting of workers. Brussels 6-10-2020. https://ec.europa.eu/info/sites/default/files/file_import/ provisionservices- posting-workers_en_0.pdf 
7. Espín Sáez, M.: De la incertidumbre y el proceso del Brexit: Qué hay de los derechos de los ciudadanos? Derecho de las relaciones laborales nº 1, pp. 56-70 (2019)

8. Fella, S., Ferguson, D., Webb, D., Jozepa, I., Ares, E., Kennedy, S.: The UK-EU Trade and Cooperation Agreement: summary and Implementation. Briefing paper $N^{\circ} 09106,30$ December 2020. House of Commons Library, p. 34. https://researchbriefings.files.parliament.uk/documents/CBP-9106/CBP9106.pdf

9. García de Cortázar y Nebreda, C.: Quo vadis tutela socialis operarium migrantium europae Cameron dixit. Revista de Derecho de la Seguridad Social. Laborum, n 3, pp. 35-58 (2015)

10. García de Cortázar y Nebreda, C.: El Brexit en el ámbito de la coordinación de regímenes de seguridad social. Revista General de Derecho del Trabajo y de la Seguridad Social, n 49 (2018)

11. García de Cortázar y Nebreda, C.: La Unión Europea y el Reino Unido. Brexit. La regulación laboral y de Seguridad Social a partir del 31 de diciembre 2020, Condenados a entenderse. Actum Social, March 2021

12. Gardeñes Santiago, M.: La circulación de personas físicas en el Acuerdo de Retirada del Reino Unido de la Unión Europea. Revista electrónica de estudios internacionales (REEI), n 40 (2020). https://doi. org/10.17103/reei.40.04

13. ICF GHK Milieu: A fact-finding analysis on the impact on the Member States' social security systems of the entitlements of non-active intra-EU migrants to special non-contributory cash benefits and healthcare granted on the basis of residence (2013). http://ec.europa.eu/social/BlobServlet?docId= 10972\&langId=en

14. Martín-Pozuelo López, A.: Retos actuales de la coordinación europea en materia de Seguridad Social: la (eterna) propuesta de reforma y el Brexit. Revista de trabajo y seguridad social. CEF $\mathrm{n}^{\circ} 439$, pp. 141-170 (2019)

15. O’Brien, C.: The ECJ sacrifices EU citizenship in vain: Commission vs UK. CMLRev, vol. 54, $n^{\circ} 1$, pp. 209-243 (2017)

16. O'Brien, C.: Unity in adversity. EU Citizenship, Social Justice and the Cautionary Tale of the UK, Hart Publishing, p. 304

17. Pérez Flores, F.J.: El estatuto juridico del demandante de empleo de la Union Europea. Revista del Ministerio de Empleo y Seguridad Social, ${ }^{\circ} 142$, pp. 17-36 (2019)

18. Ribes Moreno, M.I.: España, Gibraltar y Brexit: trabajadores ante un futuro incierto. Revista de Derecho migratorio y extranjería, $n^{\circ} 57$ (2021). Pending publication

19. Roberts, S.: Social security coordination after Brexit: trying to take an egg out of an omelette? ERA Forum 20, 531-547 (2020). https://doi.org/10.1007/s12027-019-00591-9

20. Strban, G.: Brexit and social security of mobile persons. ERA Forum 18, 165-185 (2017). https://doi. org/10.1007/s12027-017-0478-z

21. Thomas, J.: Best intentions: EU migrant workers in Fenland. The survey. The Social Market Foundation (2020)

22. UK Government: UK-EU Trade and Cooperation Agreement, December 2020. https://assets. publishing.service.gov.uk/government/uploads/system/uploads/attachment_data/file/962125/TCA_ SUMMARY_PDF_V1-.pdf

23. Verschueren, H.: Scenarios for Brexit and social security. Maastricht J. Eur. Comp. Law 24(3), 367-381 (2017)

Publisher's Note Springer Nature remains neutral with regard to jurisdictional claims in published maps and institutional affiliations. 